\title{
Studies on the inhibition of plant very-long-chain fatty acid elongase by a novel herbicide, pyroxasulfone ${ }^{\#}$
}

\author{
Yoshitaka Tanetani, ${ }^{*}$ Tomonori FuJIOKA, Koichiro KaKU and Tsutomu ShIMIZU \\ Life Science Research Institute, Kumiai Chemical Industry Co., Ltd., Shizuoka 436-0011, Japan
}

(Received October 2, 2010; Accepted November 22, 2010)

\begin{abstract}
Pyroxasulfone has been shown to be a potent inhibitor of very-long-chain fatty acid elongase (VLCFAE) of plants; therefore, it is categorized within the K3 group of herbicides. In this paper, we studied the properties of pyroxasulfone as a VLCFAE inhibitor in more detail by examination of its inhibitory effects on VLCFAEs from some plants. Pyroxasulfone inhibited microsomal VLCFAE activities of rice, Italian ryegrass, barnyard millet, wheat, corn and soybean with time-independent reversible inhibition. There were differences in the inhibitory potencies against VLCFAEs between pyroxasulfone-susceptible plants (rice, Italian ryegrass and barnyard millet) and pyroxasulfone-tolerant plants (wheat, corn and soybean). This result confirmed that the difference in the sensitivities of VLCFAEs to pyroxasulfone was one of the factors involved in the selectivity of pyroxasulfone between crops and weeds. We succeeded in preparing recombinant VLCFAEs of Arabidopsis (FAE1) and rice (Q6F365) using yeast and rice cultured cells and constructed each assay system. VLCFAE activities of FAE1 and Q6F365 were potently inhibited by pyroxasulfone; however, a critical difference was found in the inhibition manner between FAE1 and Q6F365. Pyroxasulfone inhibited FAE1 in a time-dependent manner, whereas it inhibited Q6F365 in a time-independent manner. The time-independent reversible inhibition of rice Q6F365 and microsomal VLCFAEs of plants proposes a new inhibition mechanism of VLCFAEs by pyroxasulfone. C Pesticide Science Society of Japan
\end{abstract}

Keywords: pyroxasulfone, VLCFA, VLCFAE, inhibition manner, inhibition mechanism.

\section{Introduction}

Pyroxasulfone (3-[5-(difluoromethoxy)-1-methyl-3-(trifluoromethyl) pyrazol-4-ylmethylsulfonyl]-4,5-dihydro-5,5-dimethyl1,2-oxazole; code name KIH-485) is a novel pre-emergence herbicide for use in wheat, ${ }^{1)}$ corn $^{2-6)}{ }^{20 y b e a n^{7)}}$ and other crops. ${ }^{1,8-11)}$ This herbicide provides good efficacy on both grass and broadleaf weeds. In comparison with other currently available pre-emergence herbicides for use in wheat, pyroxasulfone at the field application rate of $100 \mathrm{~g}$ a.i./ha provides efficient control of both herbicide-resistant and susceptible annual ryegrass populations. ${ }^{1)}$ The proposed label rate of this herbicide for use in corn is 200 to $300 \mathrm{~g}$ a.i./ha. ${ }^{2,3)}$ Pyroxasulfone potently inhibited shoot elongation of weeds; how-

\footnotetext{
\# Action mechanism of a novel herbicide, pyroxasulfone (part 2), see ref. 12) for part 1.

* To whom correspondence should be addressed. E-mail: y-tanetani@kumiai-chem.co.jp Published online April 2, 2011

(C) Pesticide Science Society of Japan
}

ever, selectivity was observed in growth inhibition between weeds and crops. ${ }^{1-3,5,8,10)}$ Herbicidal symptoms were similar to those of K3 herbicides categorized by the Herbicide Resistance Action Committee (HRAC), which inhibit the biosynthesis of very-long-chain fatty acids (VLCFAs) with chain lengths of 20 carbons or more.

We have shown that pyroxasulfone treatment reduced VLCFA contents and increased those of precursors of VLCFAs in rice cultured cells. ${ }^{12)}$ VLCFAE activities in etiolated rice seedlings and etiolated Italian ryegrass seedlings were potently inhibited by pyroxasulfone. These results suggested that pyroxasulfone is a potent inhibitor of plant VLCFAEs. Moderate selectivity was also found in the inhibition of VLCFAEs (elongation steps from C18: 0 to $\mathrm{C} 20$ : 0, from $\mathrm{C} 20$ : 0 to $\mathrm{C} 22: 0$ and from $\mathrm{C} 26: 0$ to $\mathrm{C} 28: 0$ ) by pyroxasulfone between pyroxasulfone-susceptible plants, such as Italian ryegrass, and pyroxasulfone-tolerant plants, such as corn. ${ }^{12)}$

It has been shown that there are many kinds of VLCFAEs in Arabidopsis and they catalyze multiple elongation steps in the biosynthesis of VLCFAs. ${ }^{13-19)}$ We have shown that multiple VLCFAEs are present in rice, and these rice VLCFAEs are 
likely targets of pyroxasulfone. ${ }^{12)}$

In this paper, we studied the properties of pyroxasulfone as an inhibitor of VLCFAEs in more detail by examination of the inhibitory effects of pyroxasulfone not only on microsomal VLCFAEs from rice, Italian ryegrass and other plants but also on recombinant VLCFAEs from rice and Arabidopsis.

\section{Materials and Methods}

\section{Chemical compounds and plant materials}

Pyroxasulfone was synthesized at KI Chemical Industry (Shizuoka, Japan) and provided to Kumiai Chemical Industry Co., Ltd. (Shizuoka, Japan). Cafenstrole was purchased from Wako Chemical Industry (Osaka, Japan). Seeds of rice (Oryza sativa L. var. Nippon-Bare), barnyard millet (Echinochloa frumentacea Link), Italian ryegrass (Lolium multiflorum Lam.), wheat (Triticum aestivum L. var. Nohrin 61), corn (Zea mays L. var. Pioneer 32K61), soybean (Glycine max L. var. Fusamidori), and Arabidopsis (Arabidopsis thaliana, ecotype Columbia-0) were purchased from markets and used in the experiments.

\section{Preparation of microsomal VLCFAEs from plants}

Microsomal fractions of etiolated plant seedlings were prepared by modifying the methods described previously. ${ }^{12)}$ In this study, VLCFAEs were prepared from etiolated plant seedlings as follows. Thirty to sixty grams of each etiolated seedling, grown for 7 days at $27^{\circ} \mathrm{C}$ on vermiculite, were ground using a mortar and pestle in 150 to $300 \mathrm{ml} \mathrm{HEPES}$ $\mathrm{KOH}$ buffer (100 mM, pH 7.2), containing $320 \mathrm{mM}$ sucrose, $10 \mathrm{mM}$ DTT, $2 \mathrm{mM}$ EDTA, 25\% (w/v) polyvinylpolypyrrolidone (PVPP), $0.02 \%(\mathrm{v} / \mathrm{v}) \mathrm{NaN}_{3}$. The following steps were carried out as reported previously. ${ }^{12)}$ The microsomal suspensions were stored at $-80^{\circ} \mathrm{C}$ until an in vitro assay.

\section{Inhibitions of microsomal VLCFAEs of plants by py- roxasulfone}

VLCFAE activity was evaluated as reported previously. ${ }^{12)}$ [2${ }^{14} \mathrm{C}$ ] malonyl-CoA $(2.03 \mathrm{MBq} / \mathrm{mmol})$ was purchased from American Radiolabeled Chemicals Inc. (St. Louis, MO). Lignoceroyl-CoA (C24:0-CoA) was purchased from Avanti POLAR LIPID Inc. (Alabaster, AL). In this study, the reaction mixture contained $20 \mu \mathrm{l}$ microsomal suspension, $5 \mu \mathrm{l}$ of $20 \mathrm{mM}$ NADH, $5 \mu \mathrm{l}$ of $20 \mathrm{mM}$ NADPH, $10 \mu \mathrm{l}$ of $200 \mu \mathrm{M}$ [2${ }^{14} \mathrm{C}$ ]-malonyl-CoA, $3 \mu \mathrm{l}$ pyroxasulfone in acetone solution, $5 \mu \mathrm{l}$ of $2 \mathrm{mM} \mathrm{C} 24: 0-\mathrm{CoA}$ and $\mathrm{H}_{2} \mathrm{O}$ to $60 \mu \mathrm{l}$ volume. The reaction mixture except for $\left[2-{ }^{14} \mathrm{C}\right]$-malonyl-CoA was pre-incubated for various time intervals at $30^{\circ} \mathrm{C}$, and then the reaction was started by the addition of $\left[2-{ }^{14} \mathrm{C}\right]$ malonyl-CoA. In the reaction without pre-incubation, microsomal suspension was added to the reaction mixture except for the microsomal fraction and then the reaction was started. The zero-time point for the reaction was used as a negative control. The following steps were carried out as described previously. ${ }^{12)}$
4. Construction of an assay system for recombinant VLCFAE of Arabidopsis

4.1. Cloning of Arabidopsis FAE1 gene into yeast cells and expression of FAE 1

Arabidopsis FAE1 gene was cloned into yeast cells as described previously. ${ }^{17)}$ Total RNA was prepared from Arabidopsis leaves with RNeasy Plant Mini Kit (Qiagen, Valencia, CA). Reverse transcription (RT) was carried out with the Transcriptor First-Strand cDNA Synthesis Kit (Roche Applied Science). Arabidopsis FAE1 gene ${ }^{17)}$ was amplified from cDNA of Arabidopsis by Phusion High Fidelity DNA polymerase (New ENGLAND BioLabs Inc., Beverly, MA, USA). The primers used for amplification of the FAE1 gene were 5' AAAAAAGGTACCATGACGTCCGTTAACGTTAAGC-3' (forward primer) and 5'-AAAAAACTCGAGGGACCGACCGTTTTGGACATGA-3' (reverse primer). The PCR product digested with KpnI and XhoI (Takara Bio, Otsu, Japan) was ligated into a yeast expression pYES2/CT vector (Invitrogen, Carlsbad, CA, USA) digested with KpnI and XhoI, with DNA Ligation Mighty Mix (Takara Bio). The obtained plasmid was introduced into Saccharomyces cerevisiae (INVSc1 strain) by the lithium acetate method. ${ }^{20}$ The obtained transformants were selected on synthetic complete medium agar plate lacking uracil (Cm-ura). Transformed yeast cells grown in $\mathrm{Cm}$-ura supplemented with $2 \%(\mathrm{w} / \mathrm{v})$ glucose were transferred to $\mathrm{Cm}$ ura supplemented with $2 \%(\mathrm{w} / \mathrm{v})$ galactose to induce the expression of C-terminus His-tagged FAE1 and harvested.

4.2. Analysis of VLCFA content in yeast cells

Contents of VLCFAs in transgenic yeast cells were analyzed as methyl esters by GC and GC/MS as reported previously. ${ }^{12)}$

4.3. Preparation of yeast microsomal fraction

Yeast microsomal fractions were prepared as reported previously. ${ }^{14,15,18)}$ Protein concentrations were determined by the method of Bradford using BSA as a standard. Microsomal fractions were stored at $-80^{\circ} \mathrm{C}$ until in vitro assay.

\subsection{Immunoblot analysis}

For Western blot analysis, $10 \mu \mathrm{g}$ microsomal proteins were separated on $10 \%$ SDS-PAGE and transferred to a polyvinylidene difluoride (PVDF) membrane (ATTO, Tokyo, Japan) by semi-dry transfer. ${ }^{21)}$ Western blot analysis was performed according to the standard protocol. C-terminus His-tagged FAE1 was detected using mouse Penta-His Antibody (Qiagen). The immunoblots were visualized using horseradish peroxidase (HRP)-conjugated anti-mouse IgG (SigmaAldrich, Piscataway, NJ) and the ECL Advance Western Blotting Detection Kit (GE Healthcare).

5. Inhibition of recombinant FAE1 of Arabidopsis by pyroxasulfone

Oleoyl-CoA (C18:1-CoA) was purchased from Sigma Aldrich. The composition of the reaction mixture was the same as described in Materials and Methods 3. except for using $10 \mu \mathrm{l}$ yeast microsomal fraction and $10 \mu \mathrm{l} \mathrm{H}_{2} \mathrm{O}$ instead of $20 \mu \mathrm{l}$ plant microsomal fraction. It was reported that there 
are two endogenous VLCFAEs, Elo2 and Elo3, in $S$. cerevisiae $^{22,23)}$; however, it was revealed that $\mathrm{K} 3$ herbicides did not inhibit their VLCFAE activity at all, but specifically inhibited the VLCFAE activity of plant VLCFAEs. Therefore, in evaluation of the inhibitory activity of pyroxasulfone on FAE1, the reaction mixture containing $100 \mu \mathrm{M}$ cafenstrole, which is known to inhibit VLCFAE activity of FAE1 completely, ${ }^{17,24)}$ was used as a negative control. The reactions were conducted at $30^{\circ} \mathrm{C}$ for $90 \mathrm{~min}$. The following steps were carried out as described previously. ${ }^{12)}$

6. Construction of an assay system for recombinant $V L$ CFAE of rice

6.1. Cloning of rice Q6F365 gene into rice cultured cells and expression of $Q 6 F 365$

The rice Q6F365 gene ${ }^{12)}$ was amplified from genomic DNA of rice by Phusion High Fidelity DNA polymerase (New ENGLAND BioLabs). The primers used in amplification of the Q6F365 gene were 5'-AAAAAATCTAGATGTTTGCTGCTTGCCATGGCCGA-3' (forward primer) and 5'-AAAAAACTTAAGTCATATGGCCGACACC-3' (reverse primer). The PCR product was digested with $A f l \mathrm{II}$ (New ENGLAND BioLabs) and blunted with T4 DNA Polymerase (Takara Bio), followed by digestion with $\mathrm{XbaI}$ (Takara Bio). Modified pSTARA R-4 binary vector plasmid, ${ }^{25)}$ in which the callus specific promoter (CSP) for driving the Q6F365 gene and NOS terminator were inserted into $\mathrm{MCS},{ }^{26)}$ was digested with SacI (Takara Bio) and blunted with T4 DNA Polymerase (Takara Bio), followed by digestion with $\mathrm{XbaI}$. The insert was ligated into the binary vector with a DNA Ligation Kit (Takara Bio). The obtained Q6F365 gene-inserted R-4 plasmid was amplified in Escherichia coli strain HST02 (Takara Bio). This binary vector plasmid was introduced into cells of Rhizobium radiobactor (Agrobacterium tumefaciens) EHA 105 strain by electroporation. Bispyribac-sodium (BS) ${ }^{27)}$ selected rice cultured cells transformed ${ }^{28)}$ with the Q6F365 gene, and those transformed with empty R-4 vector were cultivated at $27^{\circ} \mathrm{C}$ for 2 weeks in liquid MS medium containing $0.25 \mu \mathrm{M} \mathrm{BS}^{27)}$ and then harvested.

\subsection{Analysis of VLCFA content in rice cultured cells}

Contents of VLCFAs in control rice cultured cells and rice cultured cells transformed with the Q6F365 gene were compared by GC and GC/MS, as reported previously. ${ }^{12)}$

6.3. Preparation of microsomal fraction from rice cultured cells

Microsomal fractions of rice cultured cells were prepared as described previously. ${ }^{12)}$ Protein concentrations were determined by the Bradford method using BSA as a standard.

\subsection{RT-PCR analysis}

Total RNA was prepared from rice cultured cells and reverse transcription (RT) was performed according to the methods for Arabidopsis cDNA. The primers used for RT-PCR were 5'-GCAGGTTATACAGAGAAGGC-3' (forward primer) and 5'-TAGTGGTACCCCAGCTT-3' (reverse primer). In RT-PCR
Table 1. Inhibition of VLCFAEs of plants by pyroxasulfone

\begin{tabular}{ll}
\hline Enzyme Source & $\mathrm{I}_{50}(\mathrm{M})^{a)}$ \\
\hline Rice & $0.13 \times 10^{-6}$ \\
Italian ryegrass & $0.31 \times 10^{-6}$ \\
Wheat & $4.20 \times 10^{-6}$ \\
Corn & $1.71 \times 10^{-6}$
\end{tabular}

a) The molar concentrations required for $50 \%$ inhibition of plants by pyroxasulfone were calculated by the probit method.

analysis, the nucleotide from $3^{\prime}$ region of CSP to $5^{\prime}$ region of ORF of Q6F365 was amplified.

\subsection{Real-time RT-PCR analysis}

The concentrations of total RNA prepared for RT-PCR analysis were determined using a NanoDrop ND-1000 spectrometer (NanoDrop Technologies, Wilmington, DE). Reverse transcription (RT) was carried out with the PrimeScript RT Reagent Kit (Perfect Real Time) (Takara Bio). A $10 \mu \mathrm{l}$ sample of RT reaction mixture was prepared containing the following: $500 \mathrm{ng}$ total RNA, $0.5 \mu \mathrm{l}$ of $100 \mu \mathrm{M}$ random hexamer, $0.5 \mu \mathrm{l}$ of $50 \mu \mathrm{M}$ Oligo dT Primer, $2 \mu \mathrm{l}$ of $5 \times$ PrimeScript Buffer, $0.5 \mu$ PrimeScript RT Enzyme Mix I and RNase-free $\mathrm{H}_{2} \mathrm{O}$ to $10 \mu \mathrm{l}$ volume. The reaction mixture was incubated at $37^{\circ} \mathrm{C}$ for $15 \mathrm{~min}$ and reverse transcriptase was inactivated by heating at $85^{\circ} \mathrm{C}$ for $5 \mathrm{sec}$. Real-time PCR was run on a Thermal Cycler Dice Real Time System TP800 (Takara Bio). A $25 \mu \mathrm{l}$ amount of PCR reaction mixture was prepared containing the following: $2 \mu \mathrm{l} \mathrm{cDNA}, 0.2 \mu \mathrm{l}$ of $50 \mathrm{pmol} / \mu \mathrm{l}$ forward primer, $0.2 \mu \mathrm{l}$ of $50 \mathrm{pmol} / \mu \mathrm{l}$ reverse primer, $12.5 \mu \mathrm{l}$ of $2 \times$ SYBR Premix Ex Taq II and $\mathrm{H}_{2} \mathrm{O}$ to $25 \mu$ volume. Amplification conditions were as follows: $30 \mathrm{sec}$ at $95^{\circ} \mathrm{C}$, then $40 \mathrm{cy}-$ cles at $95^{\circ} \mathrm{C}$ for $5 \mathrm{sec}$ and $60^{\circ} \mathrm{C}$ for $30 \mathrm{sec}$. The primers used for amplification of the Q6F365 gene were 5'-CAAGGGGCGGATCAAGAAG-3' (forward primer) and 5'-CCACGGGT-

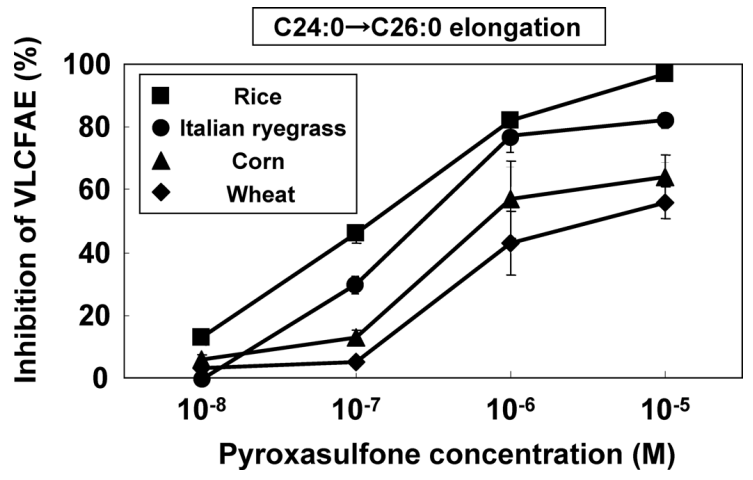

Fig. 1. Comparison of inhibition of VLCFAE activities by pyroxasulfone among rice, wheat and corn. Each data set is expressed as the mean $\pm \mathrm{SD}$ of four independent experiments. Elongation activities from $\mathrm{C} 24: 0$ to $\mathrm{C} 26: 0$ of etiolated seedlings of rice, wheat and corn were $11.2,3.5$ and $4.4 \mathrm{pmol} / 30 \mathrm{~min} / 20 \mu \mathrm{l}$ enzyme suspension, respectively. 


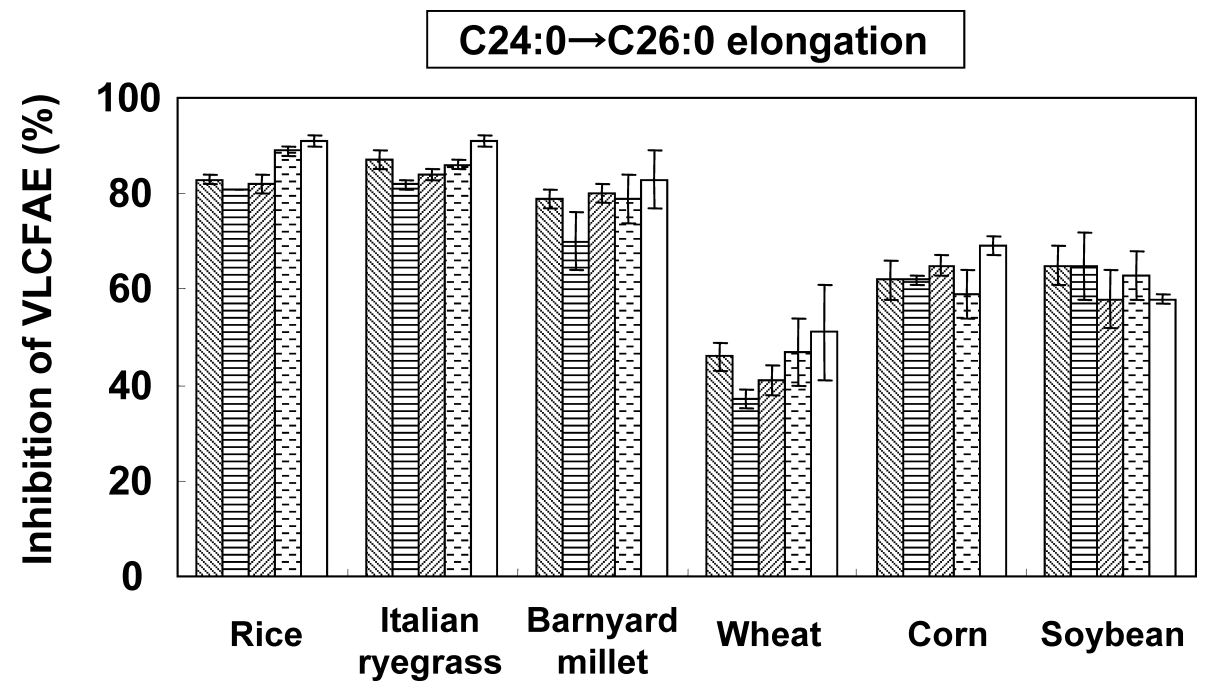

Fig. 2. Effects of pre-incubation periods on inhibition of VLCFAE activities in etiolated plant seedlings. Each data set is expressed as the mean \pm SD of four independent experiments. Elongation activities from C24:0 to C26:0 of etiolated seedlings of rice, Italian ryegrass, barnyard millet, wheat, corn and soybean were $26.9,18.0,1.2,2.3,6.3$ and $1.6 \mathrm{pmol} / 30 \mathrm{~min} / 20 \mu \mathrm{l}$ enzyme suspension, respectively. The patterns in the bar graph show the pre-incubation periods as follows: $\mathbb{Z}, 0 \mathrm{~min}$; 㞏, $5 \mathrm{~min} ; \mathbb{Z}, 10 \mathrm{~min}$; $\mathbb{E}_{-=}^{-}, 20 \mathrm{~min} ; \square, 30 \mathrm{~min}$.

TGGTGAAGTTG-3' (reverse primer); $\beta$-actin gene, 5'-CCCAAGAATGCTAAGCCAAGAG-3' (forward primer) and 5'TGATAACAGATAGGCCGGTTGAA-3' (reverse primer). The forward primer for the $\beta$-actin gene and the reverse primer for the Q6F365 gene were designed to recognize unique sequences found in the $5^{\prime}$-untranslated region and the ORF of each gene, respectively. Rice $\beta$-actin was used as an internal standard (housekeeping gene). Data analysis was carried out with the Thermal Cycler Dice Real Time System TP800 (Takara Bio).

6.6. Analysis of VLCFAE activity in rice cultured cells Stearoyl-CoA (C18:0-CoA), oleoyl-CoA (C18:1-CoA), arachidoyl-CoA (C20:0-CoA), behenoyl-CoA (C22:0-CoA) and lignoceroyl-CoA (C24:0-CoA) were used as substrates for analysis of VLCFAE activities, which were evaluated according to the methods in Materials and Methods 3. The reactions were conducted at $30^{\circ} \mathrm{C}$ for $90 \mathrm{~min}$.

7. Inhibition of recombinant Q6F365 of rice by pyroxasulfone

Inhibitory activity of pyroxasulfone on recombinant Q6F365 was examined according to Materials and Methods 3. Microsomal suspensions from control rice cultured cells and those transformed with the Q6F365 gene were used in this experiment.
(A)

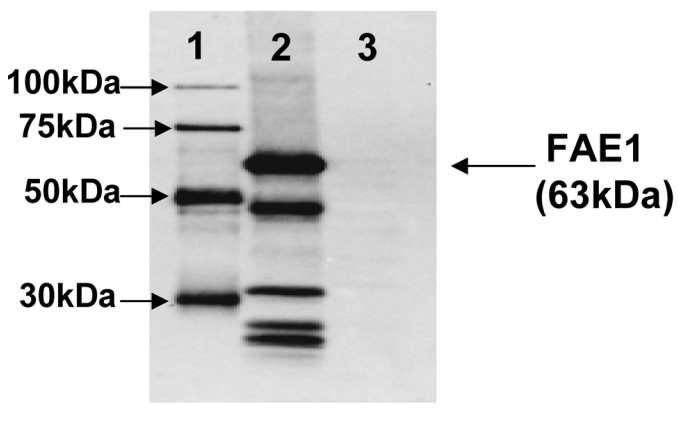

(B)

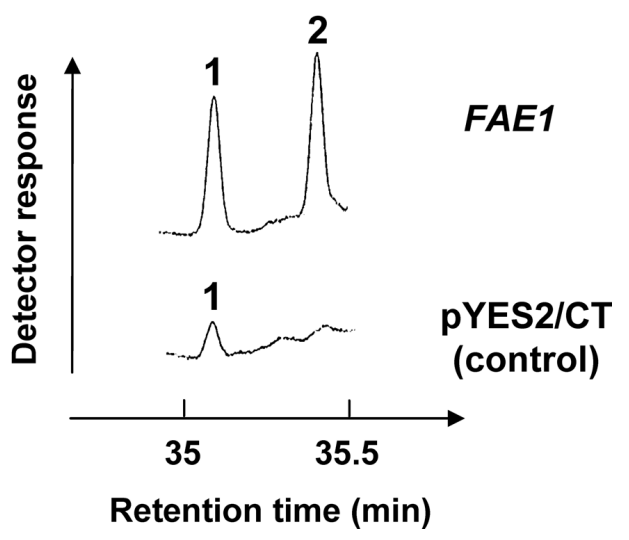

Fig. 3. Western blot analysis of FAE1 (A) and gas-chromatographic analysis of VLCFA methyl esters (B) in yeasts transformed by the Arabidopsis FAE1 gene. (A) Lane 1, Marker (6×His Protein Ladder); Lane 2, microsomal fraction of yeast transformed by FAE1 gene; Lane 3, microsomal fraction of yeast transformed by empty pYES2/CT vector (B) Gas-chromatographic pattern around C20:0 fatty acid methyl ester in transgenic yeast expressing FAE1 compared with yeast containing the empty vector is shown. VLCFA peak identities are: 1, C20:0;, C20:1. 
8. Phylogenetic analysis of amino acid sequences

Phylogenetic analysis of VLCFAE amino acid sequences of rice and Arabidopsis was performed with the ClustalW algorithm. ${ }^{29)}$ Putative rice VLCFAEs were described by Uniplot ID and Arabidopsis VLCFAEs by gene name.

\section{Results and Discussion}

\section{Inhibition of activities of microsomal VLCFAEs by py- roxasulfone}

VLCFAE activities of rice and Italian ryegrass, which catalyzes the elongation step from $\mathrm{C} 24: 0$ to $\mathrm{C} 26: 0$, were potently inhibited by pyroxasulfone. Inhibitory potencies to VLCFAE activities of wheat, corn were moderately weaker than those of rice and Italian ryegrass (Table 1, Fig. 1), suggesting that there were differences in the inhibitory potencies against VLCFAEs between pyroxasulfone-susceptible plants (rice, Italian ryegrass and barnyard millet) and tolerant plants (wheat, corn and soybean). This was considered to be one of the factors involved in the selectivity of pyroxasulfone between weeds and crops.

In general, VLCFAE-inhibiting herbicides contain a highly electrophilic carbon atom in their chemical structure. Accordingly, the inhibition mechanism of VLCFAEs by these herbicides has been assumed to be a nucleophilic reaction of the SH group of cysteine residue in the active center of VLCFAEs with the herbicides. ${ }^{24,30-32)}$ This inhibition mechanism would give a time-dependent inhibition manner by herbicides; however, pyroxasulfone inhibited VLCFAE activities, which catalyzed the elongation step from $\mathrm{C} 24: 0$ to $\mathrm{C} 26: 0$, of all plants examined in this study in a time-independent manner (Fig. 2).

\section{Construction of an assay system for a recombinant VLCFAE of Arabidopsis}

Eight out of 21 putative Arabidopsis VLCFAEs have been characterized. ${ }^{13-19)}$ We prepared yeast cells which are transformed by the Arabidopsis FAE1 gene. ${ }^{17)}$ FAE1 protein expression in transformed yeast cells was confirmed by Western blot analysis (Fig. 3A). The transformed yeast cells accumulated much more VLCFAs, such as C20:0 and C20:1, than the control, which was transformed with the empty vector plasmid (Fig. 3B). Construction of an assay system for recombinant FAE1 was confirmed by these results.

\section{Inhibition of a recombinant FAE1 of Arabidopsis by pyroxasulfone}

Shoot elongation of Arabidopsis was potently inhibited by pyroxasulfone over $10^{-6} \mathrm{M}$ concentration (data not shown). Pyroxasulfone potently inhibited VLCFAE activity of the recombinant FAE1 in microsomes prepared from transformed yeast cells, which catalyzed the elongation step from $\mathrm{C} 18: 1$ to C20: 1 (Fig. 4A). Also, pyroxasulfone inhibited the VLCFAE activity of FAE1 in a time-dependent manner, indicating that the inhibition manner of FAE1 by pyroxasulfone might be ir-
(A)

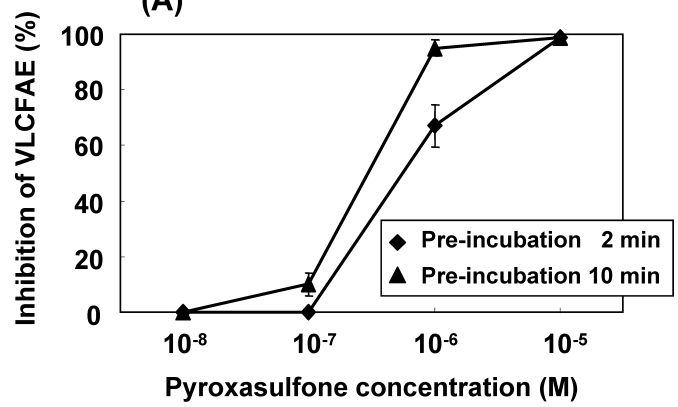

(B)

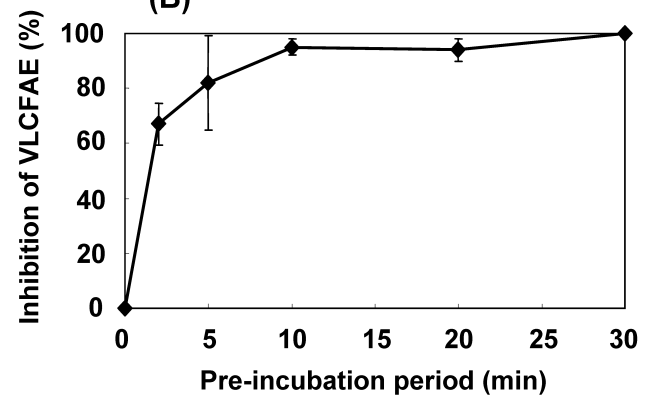

(C)

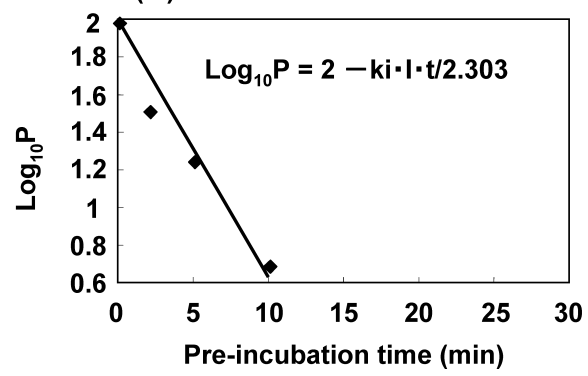

Fig. 4. Inhibitory effects of pyroxasulfone on VLCFAE activity of recombinant Arabidopsis FAE1. Each data set is expressed as the mean $\pm \mathrm{SD}$ of three or four independent experiences. (A) Inhibitory potencies against VLCFAE activity of FAE1, which catalyzes the elongation step from C18:1 to C20:1. VLCFAE activity of recombinant FAE1, which catalyzes the elongation step from $\mathrm{C} 18: 1$ to C20: 1 , was $2.7 \mathrm{nmol} / \mathrm{mg}$ protein $/ 90 \mathrm{~min}$. (B) Inhibition of FAE1 by $10^{-6}$ molar concentration of pyroxasulfone. VLCFAE activity of recombinant FAE1, which catalyzes the elongation step from $\mathrm{C} 18: 1$ to $\mathrm{C} 20: 1$, was $2.7 \mathrm{nmol} / \mathrm{mg}$ protein $/ 90 \mathrm{~min}$. (C) Pseudo-first order reaction plots for the irreversible inhibition of FAE1 by pyroxasulfone using the data in Fig. 4B. P, residual activity of FAE1 (\% of control); ki, pseudo-first order rate constant; I, pyroxasulfone concentration (M); t, pre-incubation time ( $\mathrm{min})$.

reversible (Fig. 4B). The pseudo-first order rate constant (ki) of the irreversible inhibition of FAE1 by pyroxasulfone was calculated to be $3.2 \times 10^{5} \mathrm{M}^{-1} \cdot \mathrm{min}^{-1}$ (Fig. 4C). Based on these results, the inhibition of FAE1 by pyroxasulfone is assumed to be due to the nucleophilic reaction of the SH group 
(A)

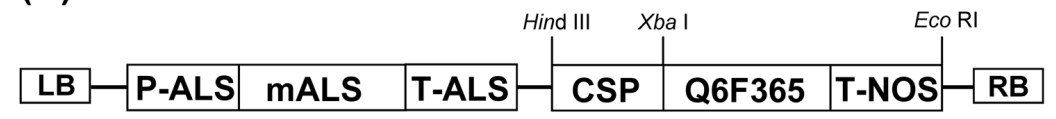

(B)

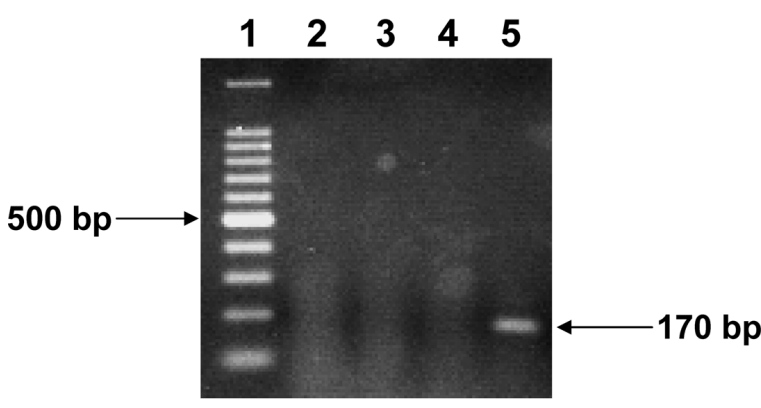

(C)

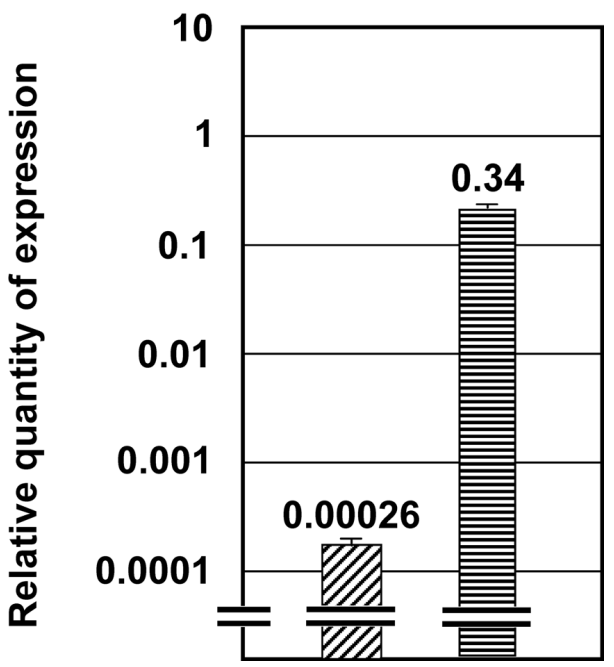

Fig. 5. T-DNA construct in binary R-4 vector plasmid containing Q6F365 gene (A) and expression analysis of Q6F365 gene in rice cultured cells by RT-PCR (B) and real-time RT-PCR (C). (A) The letters show the genes as follows: P-ALS, rice ALS promoter; mALS, rice W548L/S627I mutated ALS gene; T-ALS, rice ALS terminator; CSP, rice 674bp callus specific promoter (CSP); T-NOS, nopaline synthetase terminator; LB and RB, T-DNA left and right border repeats. As CSP, the 1032nd to 1705th nucleotide sequence of SEQ ID NO1 of reference 29 was used. (B) Different sources of rice cultured cells were used as templates for RT-PCR as follows: Total RNA from control rice cultured cells (Lane 2); cDNA from control rice cultured cells (Lane 3); total RNA from rice cultured cells transformed with Q6F365 gene (Lane 4); cDNA from rice cultured cells transformed with Q6F365 gene (Lane 5). 100bp ladder was loaded in Lane 1. (C) Relative quantity of Q6F365 gene expression is shown. The expression of $\beta$-actin gene was used as the internal standard. Each data set is expressed as the mean \pm SD of four independent experiments. $\mathbb{Z}$, rice cultured cells transformed with empty R-4 vector; $\equiv$, rice cultured cells transformed with Q6F365 gene.

of cysteine residue in the active center with pyroxasulfone, which is consistent with the previously supported hypothesis. $^{24,30-32)}$

\section{Construction of an assay system for a recombinant VLCFAE of rice}

At least 14 putative rice VLCFAEs have been found by blastp search with the amino acid sequences of several Arabidopsis VLCFAEs. ${ }^{12)}$ We attempted to construct an assay system for recombinant VLCFAEs using yeast cells; however, introduced rice VLCFAE genes were slightly expressed or were not expressed at all in transformed yeast cells (data not shown), suggesting that it is difficult to construct an assay system for rice VLCFAEs with yeast cells. Then, we tried to develop an assay system using rice cultured cells. In this method, we chosen Q6F365 and Q5Z6S3 genes, which are rarely expressed in rice cultured cells but are strongly expressed in rice roots and rice shoots, respectively, based on the results of the gene expression profile using a microarray. ${ }^{12)}$ Transformed rice cul- tured cells were cultivated and then the expression of introduced genes, VLCFA contents and VLCFAE activities of those rice cultured cells were evaluated. In rice cultured cells transformed with the Q6F365 gene (Fig. 5A), the expression of the Q6F365 gene driven by callus specific promoter (CSP) was confirmed by RT-PCR (Fig. 5B, Lane 5). It was also shown that the quantity of Q6F365 gene expression in rice cultured cells transformed with the Q6F365 gene was approximately 1300-fold higher than that of the endogenous Q6F365 gene in control rice cultured cells by real-time RT-PCR (Fig. 5C). These expression analyses by RT-PCR and real-time RTPCR suggested that the Q6F365 gene driven by CSP was strongly expressed in rice cultured cells transformed by the Q6F365 gene. In addition, higher accumulation of VLCFAs and stronger VLCFAE activities than those in the control were observed in rice cultured cells transformed with the Q6F365 gene (Fig. 6A, 6B). These results suggested not only that the construction of an assay system for recombinant Q6F365 was successful but also that Q6F365 was one of the rice VL- 
(A)

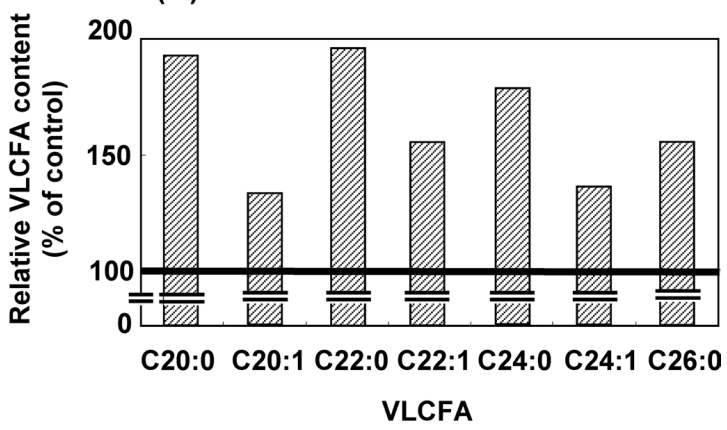

(B)

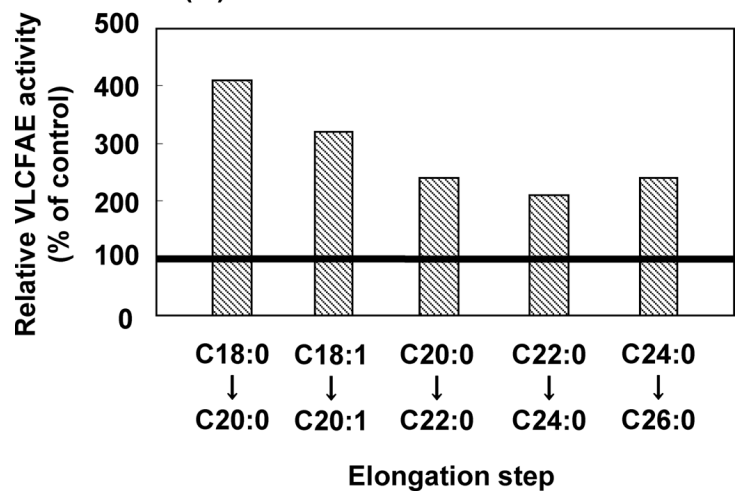

Fig. 6. Relative VLCFA content (A) and VLCFAE activity (B) in rice cultured cells transformed with Q6F365 gene. (A) Contents of $\mathrm{C} 20: 0, \mathrm{C} 20: 1, \mathrm{C} 22: 0, \mathrm{C} 22: 1, \mathrm{C} 24: 0, \mathrm{C} 24: 1$ and $\mathrm{C} 26: 0$ in control rice cultured cells were 50.82, 58.52, 87.45, 41.91, 104.73, 67.28 and $13.57 \mu \mathrm{g} / \mathrm{g} \mathrm{FW}$, respectively. On the other hand, those in rice cultured cells transformed with Q6F365 gene were 98.23, 78.61, 171.46, $64.92,185.34,90.67$ and $20.99 \mu \mathrm{g} / \mathrm{g} \mathrm{FW}$, respectively. (B) VLCFAE activities, which catalyze the elongation steps from $\mathrm{C} 18: 0$ to $\mathrm{C} 20: 0$, $\mathrm{C} 18: 1$ to $\mathrm{C} 20: 1, \mathrm{C} 20: 0$ to $\mathrm{C} 22: 0, \mathrm{C} 22: 0$ to $\mathrm{C} 24: 0$ and $\mathrm{C} 24: 0$ to $\mathrm{C} 26: 0$ in the control were $15.9,8.7,12.8,9.5$ and $9.4 \mathrm{pmol} / \mathrm{mg}$ protein/90 min, respectively. On the other hand, those in rice cultured cells transformed with Q6F365 gene were 65.4, 27.3, 30.9, 20.0 and $22.9 \mathrm{pmol} / \mathrm{mg}$ protein $/ 90 \mathrm{~min}$, respectively.

CFAEs, which catalyzed the elongation steps from $\mathrm{C} 18: 0$ to $\mathrm{C} 20: 0, \mathrm{C} 18: 1$ to $\mathrm{C} 20: 1, \mathrm{C} 20: 0$ to $\mathrm{C} 22: 0, \mathrm{C} 22: 0$ to $\mathrm{C} 24: 0$ and $\mathrm{C} 24: 0$ to $\mathrm{C} 26: 0$. On the other hand, the construction of an assay system for recombinant Q5Z6S3 was unsuccessful (data not shown).

\section{Inhibition of a recombinant Q6F365 of rice by pyroxa- sulfone}

VLCFAE activities in rice cultured cells transformed with the Q6F365 gene was assumed to be the sum of those in the control (A) and that of recombinant Q6F365 expressed in rice cultured cells transformed with the Q6F365 gene (B). Thus, the inhibition percentage of VLCFAE activity in rice cultured cells transformed with the Q6F365 gene (Z) was assumed to be the sum of that in the control $(\mathrm{X})$ and that of recombinant
Q6F365 expressed in rice cultured cells (Y). Accordingly, the equation: $\mathrm{Z}=(\mathrm{AX}+\mathrm{BY}) / \mathrm{A}+\mathrm{B}$, which corresponds to the equation: $\mathrm{Y}=\mathrm{Z}+\mathrm{A}(\mathrm{Z}-\mathrm{X}) / \mathrm{B}$, would be applied to elucidate the inhibitory activity of pyroxasulfone on Q6F365; therefore, $\mathrm{Y}$ was found from calculations using the experimental data of A, B, X and Z.

Pyroxasulfone inhibited the VLCFAE activities of recombinant Q6F365, which catalyzed the elongation steps from C18:0 to C20:0 and C20:0 to C22:0, respectively (Fig. 7A). Also, pyroxasulfone inhibited the VLCFAE activity of recombinant Q6F365, which catalyzes the elongation step from $\mathrm{C} 18$ :0 to $\mathrm{C} 20$ :0 in a time-independent manner (Fig. 7B). This inhibition manner was different from that of FAE1, indicating that the inhibition mechanism of Q6F365 by pyroxasulfone is reversible; therefore, it was considered that pyroxasulfone might not react with the $\mathrm{SH}$ group of the cysteine residue in the active center of Q6F365. This result showed a new inhibition mechanism of a VLCFAE by pyroxasulfone.

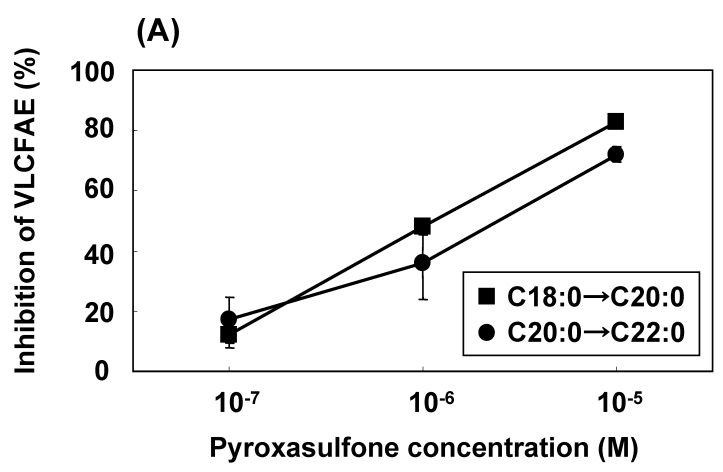

(B)

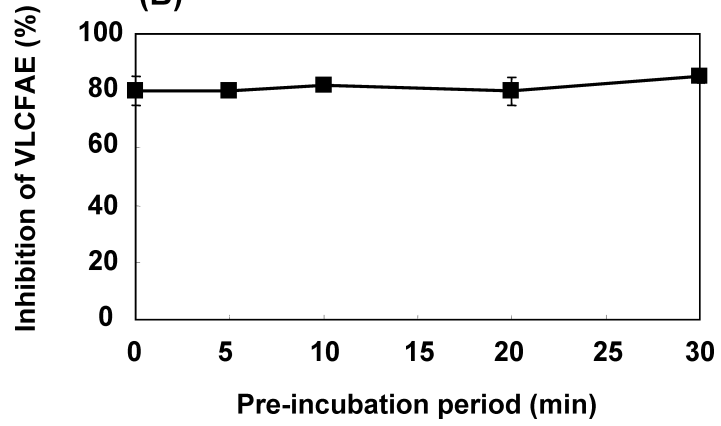

Fig. 7. Inhibitory effects of pyroxasulfone on VLCFAE activity of recombinant rice Q6F365. Each data set is expressed as the mean $\pm \mathrm{SD}$ of three or four independent experiences. (A) Inhibitory potencies against VLCFAE activities of Q6F365 under the conditions of $10 \mathrm{~min}$ pre-incubation of microsomes with pyroxasulfone. VLCFAE activities of recombinant rice Q6F365, which catalyzes the elongation step from $\mathrm{C} 18: 0$ to $\mathrm{C} 20: 0$ and from $\mathrm{C} 20: 0$ to $\mathrm{C} 22: 0$, were 93.2 and $14.1 \mathrm{pmol} / \mathrm{mg}$ protein $/ 30 \mathrm{~min}$, respectively. (B) Inhibition at different pre-incubation periods using recombinant Q6F365 by $10^{-5}$ molar concentration of pyroxasulfone. VLCFAE activity of recombinant Q6F365, which catalyzes the elongation step from $\mathrm{C} 18: 0$ to $\mathrm{C} 20$ : 0 , was $79.4 \mathrm{pmol} / \mathrm{mg}$ protein $/ 30 \mathrm{~min}$. 


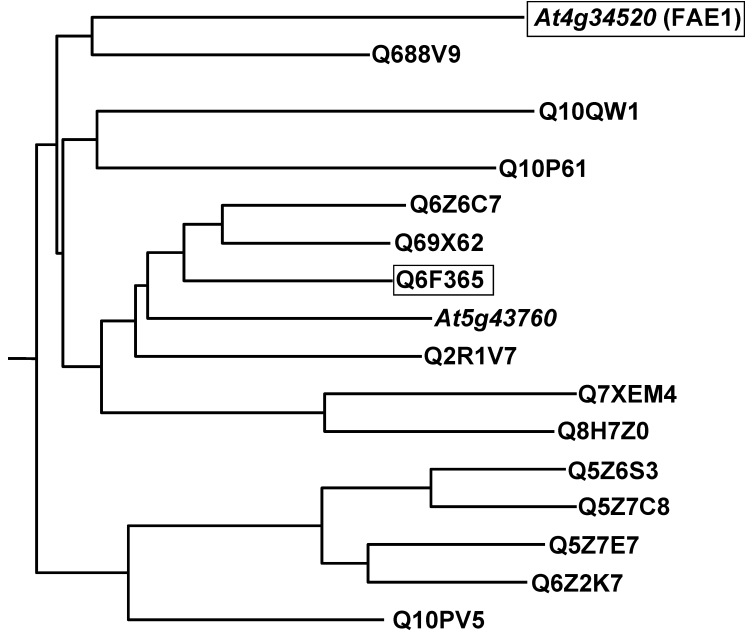

Fig. 8. Phylogenetic tree for Arabidopsis VLCFAEs and putative rice VLCFAEs based on amino acid sequences. Putative rice VLCFAEs are described by Uniplot ID and two Arabidopsis VLCFAEs are described by gene name.

\section{Phylogenetic analysis of genome sequence}

We performed phylogenetic analysis with the ClustalW algorithm based on amino acid sequences of 14 putative rice VLCFAEs containing two Arabidopsis VLCFAEs, such as At4g34520 (FAE1) and At5g43760 (Fig. 8). As a result, rice Q6F365 was remotely clustered from Arabidopsis FAE1 in the phylogenetic tree (Fig. 8). As described above, a critical difference was found in the inhibition manner by pyroxasulfone between FAE1 and Q6F365 (Figs. 4B, 7B). This difference might depend on the difference in enzymatic properties between FAE1 and Q6F365, which was implied by phylogenetic analysis.

Considering that the inhibition manner of microsomal VLCFAEs of the tested plants by pyroxasulfone was time-independent, as was that of recombinant Q6F365 (Figs. 2, 7B), most plant VLCFAEs were presumed to be inhibited in a time-independent manner. In order to elucidate the inhibition mechanism in more detail, we need to study that of each VLCFAE of Arabidopsis, rice and other plants by pyroxasulfone. The time-independent reversible inhibition of rice Q6F365 and microsomal VLCFAEs of the tested plants proposes a new inhibition mechanism of VLCFAEs by pyroxasulfone. This might alter the former hypothesis ${ }^{24,30-32}$ of the inhibition mechanism of VLCFAE-inhibiting herbicides that the SH group of cysteine residue in the active center of VLCFAEs reacts with them by a nucleophilic reaction.

\section{References}

1) M. J. Walsh, T. M. Flower, B. Crowe, M. Clarke, T. Ambe and S B. Powles: Weed Technol. in press.

2) P. W. Geier, P. W. Stahlman and J. C. Frihauf: Weed Technol. 20 622-626 (2006)

3) S. R. Sikkema, N. Soltani, P. H. Sikkema and D. E. Robinson: Hort Science 43, 170-172 (2008).
4) S. R. King and J. O. Garcia: Weed Technol. 22, 420-424 (2008).

5) S. Z. Knezvic, A. Datta, J. Scott and P. J. Porpiglia: Weed Technol. 23, 34-39 (2009).

6) N. Soltani, M. Kumagai, L. Brown and P. H. Sikkema: Can. J. Plant Sci. 90, 241-245 (2010).

7) S. M. Ulloa and M. D. K. Owen: Weed Sci. 57, 74-80 (2009).

8) G. L. Steele, P. J. Porpiglia and J. M. Chandler: Weed Technol. 19, 866-869 (2005).

9) S. R. King, R. L. Ritter, E. S. Hagood Jr. and H. Menbere: Weed Technol. 21, 578-582 (2007)

10) P. H. Sikkema, D. E. Robinson, R. E. Nurse and N. Soltani: Crop Prot. 27, 124-129 (2008).

11) C. L. Stewart, R. E. Nurse, C. Gillard and P. H. Sikkema: Weed Biol. Manag. 10, 40-47 (2010).

12) Y. Tanetani, K. Kawai, K. Kaku, T. Fujioka and T. Shimizu: Pestic. Biochem. Physiol. 95, 47-55 (2009).

13) A. A. Millar, S. Clemens, S. Zachgo, E. M. Giblin and D. C. Taylor: Plant Cell 11, 825-838 (1999).

14) M. Ghanevati and J. G. Jaworski: Biochem. Biophys. Acta 15, 77-85 (2001).

15) M. Ghanevati and J. G. Jaworski: Eur. J. Biochem. 269, 35313539 (2002).

16) C. Lechelt-Kunze, R. C. Meissner, M. Drews and K. Tietjen: Pest. Manag. Sci. 59, 847-856 (2003).

17) S. Trenkamp, W. Martin and K. Tietjen: Proc. Natl. Acad. Sci. USA 101, 11903-11908 (2004).

18) B. J. Blacklock and J. G. Jaworski: Biochem. Biophys. Res. Commun. 346, 583-590 (2006).

19) J. Joubes, S. Raffaele, B. Bourdeux, C. Garcia, J. LarocheTraineau, P. Moreau, F. Domergue and R. Leissire: Plant Mol. Biol. 67, 547-566 (2008).

20) R. D. Gietz and R. A. Woods: "Molecular Genetics of Yeast: Practical Approaches," ed. by J. A. Johnston, Oxford University Press, Oxford, pp. 121-134, 1994.

21) J. Kyhse-Andersen: J. Biochem. Biophys. Methods 10, 203-209 (1984).

22) C. S. Oh, D. A. Toke, S. Mandala and C. E. Martin: J. Biol. Chem. 272, 17376-17384 (1997).

23) S. Paul, K. Gable, F. Beandoin, E. Cahoon, J. Jaworski, J. A. Napier and T. M. Dunn: J. Biol. Chem. 281, 9018-9029 (2006).

24) P. Böger: J. Pestic. Sci. 28, 324-329 (2003).

25) http://www.kumiai-chem.co.jp/palselect/image/pstara_gazo06_ 1.gif/Accessed 30 Sep., 2010.

26) H. Otsuki and M. Oshima (National Institute of Crop Science): US Patent 0223438 (2005)

27) http://www.kumiai-chem.co.jp/palselect/pstara_ex.html/Accessed 30 Sep., 2010

28) S. Toki: Plant Mol. Biol. Rep. 15, 16-21 (1997).

29) http://align.genome.jp/Accessed 30 Sep., 2010.

30) P. Böger, B. Matthes and J. Schmalfu B: Pest. Manag. Sci. 56, 497-508 (2000).

31) P. Böger and B. Matthes: "Herbicide Classes in DevelopmentMode of Action, Targets, Genetic Engineering, Chemistry," ed. by P. Böger, K. Wakabayashi and K. Hirai, Springer Publ., Berlin, Heidelberg, pp. 115-137, 2002.

32) C. Eckermann, B. Matthes, M. Nimtz, V. Reiser, B. Lederer, P. Böger and J. Schroder: Phytochem. 64, 1045-1054 (2003). 